\title{
Natural Banana (Musa acuminate) Peel: an Unconventional Adsorbent for Removal of Fluoride from Aqueous Solution through Batch Study
}

\author{
Naba Kumar Mondal ${ }^{1}$
}

Received: 17 September 2016 / Revised: 15 November 2016 / Accepted: 16 November 2016 / Published online: 29 November 2016

(C) Springer Science+Business Media Singapore 2016

\begin{abstract}
Higher level of fluoride in underground water is a burning problem in many parts of the world. Continuous ingestion of fluoride containing water leads to fluorosis. In the present work, natural banana (Musa acuminate) peel (NBP), an unconventional adsorbent, has been explored for removal of fluoride from aqueous system. The NBP was characterized by using SEM, FTIR, and point of zero charge. In the batch study, maximum fluoride removal was achieved at the $\mathrm{pH} 4.0$ $\left(\mathrm{pH}_{\mathrm{ZPC}} 5.63\right)$, taking about $60 \mathrm{~min}$ to attain equilibrium. Kinetics data were fitted with a pseudo-second-order $\left(R^{2}=0.99\right)$ and Bahangam models $\left(R^{2}=1.00\right)$. The experimental data fitted well to a $\mathrm{D}-\mathrm{R}$ adsorption isotherm $\left(R^{2}=0.995\right)$. Thermodynamic data suggests that the adsorption of fluoride on NBP is an exothermic reaction. Therefore, the results suggest that natural banana peel dust could be a cost-effective, eco-friendly adsorbent for removal of fluoride from aqueous medium.
\end{abstract}

Keywords Banana peel $\cdot$ Fluoride $\cdot$ Batch study .

Regeneration

\section{Introduction}

Due to rapid industrialization, huge quantity of pollutants discharges in to the environment. Fluorine is one such pollutant

Electronic supplementary material The online version of this article (doi:10.1007/s41101-016-0015-x) contains supplementary material, which is available to authorized users.

Naba Kumar Mondal

nkmenvbu@gmail.com

1 Environmental Chemistry Laboratory, Department of Environmental Science, The University of Burdwan, Burdwan, West Bengal, India that threatens living organisms, in particular, humans [1]. Fluorine is the strongest electronegative element and belongs to group 17 in modern periodic table. Its atomic number and molecular weight is 9 and 19, respectively [2]. Very small quantity of fluorine is required for hardening of enamel and protection against dental caries. The excessive intake of fluoride leads to dental as well as skeletal fluorosis [3]. Apart from dental and skeletal fluorosis, fluoride can bind to the functional amino acid groups located around the active center of an enzyme to cause an in inhibitory effect which leads to decrease enzyme activity [4]. The main source of fluoride in the environment is entirely geogenic in nature [5]. However, recently, literature cited that it enters through anthropogenic activities such as industrial drains [1]. Very recently, Das et al. [6] and Maitra et al. [7] highlighted that fluoride can interfere in the plant system also. Due to its strong negative impact on both animal and plant kingdom, the World Health Organization (WHO) has set a stringent guideline value of fluoride in drinking water at $1.5 \mathrm{mg} / \mathrm{L}$. [8]. The problem with high fluoride in drinking water is a major problem in several tropical countries like India [9]. The only possible remedy of this problem is defluoridation [10].

Many techniques are available to remove fluoride from contaminated water such as reverse osmosis, electrodialysis, Donan dialysis, nanofiltration, and ion exchange [11]. But very recently, attention of scientists has been focused to use very low-cost, easily available materials [12]. A good number of low cost materials have been tested such as sugarcane ash [13], Tea ash [14], coconut fiber dust [15], lemon leaf dust [16], egg shell dust [17], calcareous soil [18], and rice husk ash [19]. However, most of the adsorbents are suitable at lower concentration and showed excellent performance at an extreme $\mathrm{pH}$ value, such as activated coal showed good fluoride uptake capacity at $\mathrm{pH}$ less than 3 [20]. Therefore, it is a great challenge among the scientists to explore low-cost, easily 
available, and eco-friendly adsorbents which remove fluoride from contaminated water under neural $\mathrm{pH}$ [21].

Fruits peels have attracted considerable interest as potential candidates for removal of pollutants from aqueous solution due to their inexpensiveness, availability, environmental stability, and high surface area/sorption capacity [15]. Among the various fruits peel, banana peel is a major waste in many countries including India. Previous literature highlighted that banana peel extensively used for removal of heavy metals [22, 23]. But very handful of researcher tried to use banana peel as an adsorbent for removal of fluoride. From this viewpoint, present research has been formulated with the following objectives: (i) to prepare banana peel dust, (ii) to characterization of adsorbent through SEM, FTIR, and $\mathrm{pH}_{\mathrm{ZPC}}$, study; (iii) the experimental data will fitted in various isotherm, kinetic, and thermodynamics equations; (iv) comparative study with previously published adsorbents; and (v) application of banana peel dust for defluoridation from filed samples.

\section{Materials and Methods}

\section{Preparation of Natural Banana Peel Dust}

The raw waste banaba peels (Musa acuminate) were collected from nearby fruits stall of Burdwan town, West Bengal. After collection, peels were thoroughly washed with tap water followed by washing with de-ionized water and dried in hot air oven at $50^{\circ} \mathrm{C}$ for $12 \mathrm{~h}$. The dried peels were cut into small pieces and again dried in hot air oven for $24 \mathrm{~h}$, maintaining $60{ }^{\circ} \mathrm{C}$ temperature. The dried banana peels were grinded in kitchen grinder to get the desired particle size $(200 \mu \mathrm{m})$ using suitable the powder form of banana peel was stored in air light container (Table 1).

Table 1 Physical characteristics of banana peel

\begin{tabular}{lc}
\hline Parameter & \multicolumn{1}{l}{ Values } \\
\hline $\mathrm{pH}$ & $6.59 \pm 0.41$ \\
Conductivity $(\mathrm{mS} / \mathrm{cm})$ & $190 \pm 3.89$ \\
Specific gravity & $2.66 \pm 0.31$ \\
Bulk density $\left(\mathrm{g} / \mathrm{cm}^{3}\right)$ & $0.384 \pm 0.11$ \\
Particle density $\left(\mathrm{g} / \mathrm{cm}^{3}\right)$ & $0.138 \pm 0.01$ \\
Porosity $(\%)$ & $178.26 \pm 11.65$ \\
Moisture content $(\%)$ & $2.98 \pm 0.02$ \\
$\mathrm{P}_{\text {zpc }}^{\mathrm{H}}$ & $5.63 \pm 0.05$ \\
Dry matter & $89.73 \pm 2.34$ \\
Crude fiber & $10.33 \pm 1.01$ \\
Ash & $17.94 \pm 0.04$ \\
\hline
\end{tabular}

Mean \pm SD

\section{Point of Zero Charge ( $\left.\mathrm{pH}_{\mathrm{ZPC}}\right)$}

Zero point charge of the NBP was determined by following the solid addition method [24]. Initially, a series of conical flasks were taken with $50 \mathrm{~mL}$ of $0.1(\mathrm{M}) \mathrm{KNO}_{3}$ solutions in each flask along with $0.1 \mathrm{~g}$ NBP. The $\mathrm{pH}$ of the $0.1(\mathrm{M}) \mathrm{KNO}_{3}$ solutions was adjusted by using $0.05(\mathrm{~N}) \mathrm{HNO}_{3}$ and $0.1(\mathrm{~N})$ $\mathrm{KOH}$ solution. After thoroughly shaking $(24 \mathrm{~h})$, the $\mathrm{pH}$ of the final solutions was recorded and a graph was constructed by $\mathrm{pH}$ vs $\Delta \mathrm{pH}$.

\section{Adsorption Experiments}

The entire adsorption experiment was carried out by varying the operating variables such as $\mathrm{pH}$, initial adsorbate concentration ( $\mathrm{ppm})$, dose $(\mathrm{g})$, adsorbent particle size, contact time (min), shaking speed, and temperature (K). Batch experiments were carried out in a $250-\mathrm{ml}$ conical flask containing fluoride solution $(2.0-20.0 \mathrm{ppm})$ with varying adsorbent dose $\left(0.1-10 \mathrm{gL}^{-1}\right)$. The $\mathrm{pH}$ of the respective solutions was maintained by using $0.1(\mathrm{~N}) \mathrm{HCl}$ and/or $0.1(\mathrm{~N}) \mathrm{NaOH}$. The contact time was $(5-80 \mathrm{~min})$ and temperature (300-333 K). After adsorption, the residual fluoride concentration was measured by ion selective electrode (Orion 4 star). The fluoride sample solution and fluoride standard solutions were diluted 1:1 with a TISAB solution [25]. The percentage of fluoride adsorption was calculated by using the following Eq. (1):

$\operatorname{Removal}(\%)=\frac{\left(C_{0}-C_{e}\right)}{C_{0}} \times 100$

The adsorption capacity ( $\mathrm{mg} / \mathrm{g}$ ) of the experimental adsorbent was calculated by using the following Eq. (2):

$q_{e}=\frac{\left(C_{0}-C_{e}\right) V}{m}$

where $C_{0}$ and $C_{e}$ denoted the initial and equilibrium fluoride ion concentrations $(\mathrm{mg} / \mathrm{L})$, respectively. $V$ is the volume of the solution in liters, and $m$ is the mass of the adsorbent used (g).

\section{Instrumentation}

A number of instruments were used for characterization of adsorbent and estimation of fluoride from aqueous medium such as scanning electron microscop (SEM) (HITACHI-S-530, Scanning Electron Microscope and ELKO Engineering) at an accelerating voltage of $20.0 \mathrm{kV}$, Fourier transform infrared spectroscopy (FTIR) (BRUKER, Tensor 27), and ion selective electrode (Orion 4 star). 


\section{Results and Discussion}

\section{Zero Point Charge of NBP}

From Fig. 1, it is clear that the $\mathrm{pH}_{\mathrm{ZPC}}$ of NBP is 5.63. That means, at this $\mathrm{pH}$, the surface of NBP has no charge. However, below the $\mathrm{pH}$ (5.63), surface of NBP changes to positive and above the $\mathrm{pH}$ (5.63), the surface is negatively charged.

\section{FTIR Analysis}

FTIR is a valuable technique to identify the function groups present on the surface of the adsorbents. Present adsorbent exhibit various sharp peaks such as $3905-3258 \mathrm{~cm}^{-1}$ which is attributed to the alcoholic -OH stretching; 1631, 1269' and $1116-624 \mathrm{~cm}^{-1}$, respectively, assigned to $-\mathrm{C}=\mathrm{O}$ stretching of carboxylic acid or ester or ether and N-H deformation of amines, respectively (Figure Supply 1). After adsorption, the shifting of -OH and the slight decrease in intensity indicate the involvement of $\mathrm{OH}$ in the fluoride adsorption (Figure not supplied). Almost similar observation was reported by Mondal et al. [14] for removal of fluoride by using low-cost waste tea ash as adsorbent.

\section{SEM Analysis}

Scanning electron micrograph has immense potentiality for understanding the surface morphology of the adsorbents. SEM photograph of NBP before and after loading of fluoride was presented in the Fig. 2a, b. From Fig. 2a, it is clearly revealed that the surface of NBP has numerous micro-rough, porous structures which might be the area of fluoride loading. However, after fluoride removal, the surface of NBP does not exhibit such rough areas as before (Fig.2b). Almost similar peel SEM structure of banana and orange has been demonstrated by previous researchers for removal of heavy metals from aqueous solution [26]. This observation clearly indicates

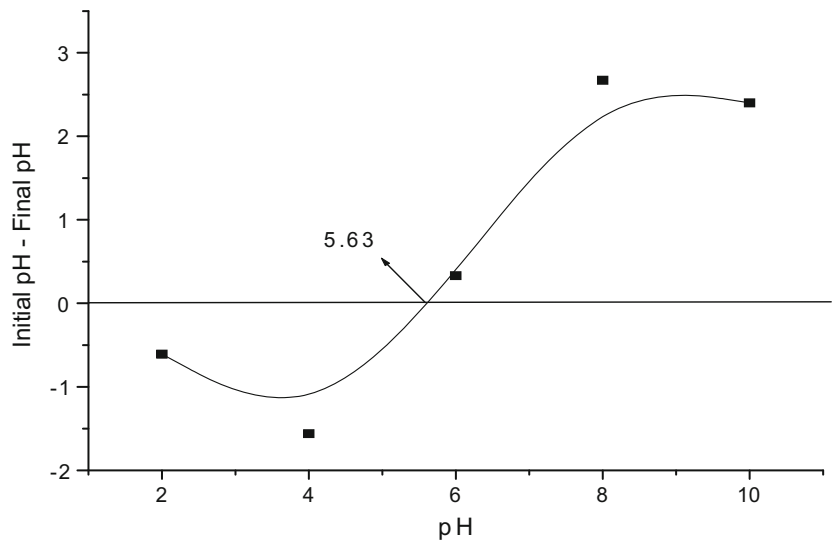

Fig. 1 ZPC of Banana peel dust

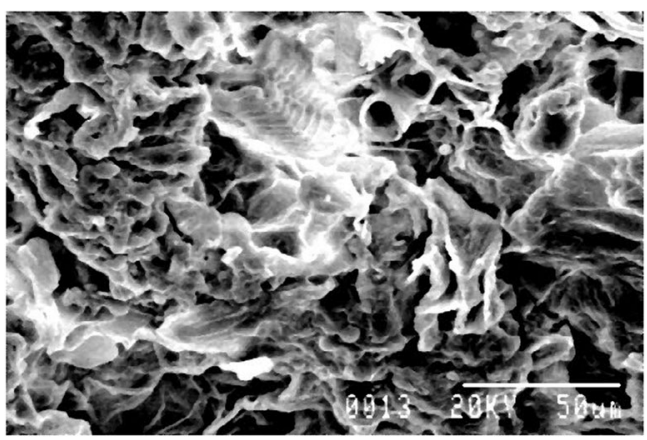

(a)

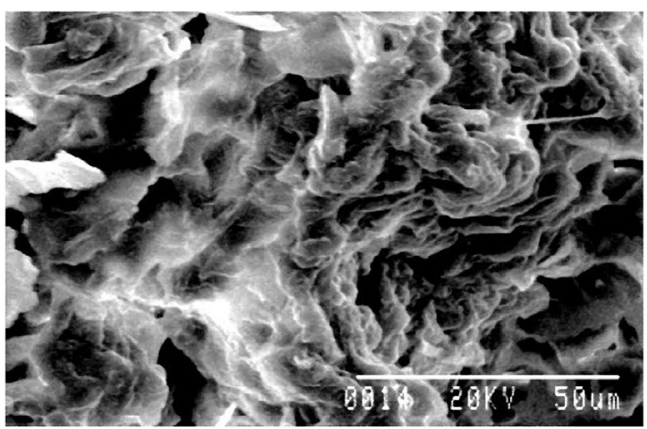

(b)

Fig. 2 Scanning electron microscopy of Banana peel. a Before passing fluoride solution $(1500 \times$ magnification). b After passing fluoride solution $(\times 1500$ magnification $)$

that NBP has tremendous role towards the affinity of fluoride binding.

\section{Effect of pH}

$\mathrm{pH}$ of the solution has remarkable role in both metal and nonmetal adsorption process [26]. Figure 3 clearly revealed that $\mathrm{F}$ removal remarkable elevated with changing $\mathrm{pH}$ from 2.0 to 4.0. However, after $\mathrm{pH} 4$, the removal of $\mathrm{F}$ adsorption sharply declines with increasing alkalinity of the fluoride

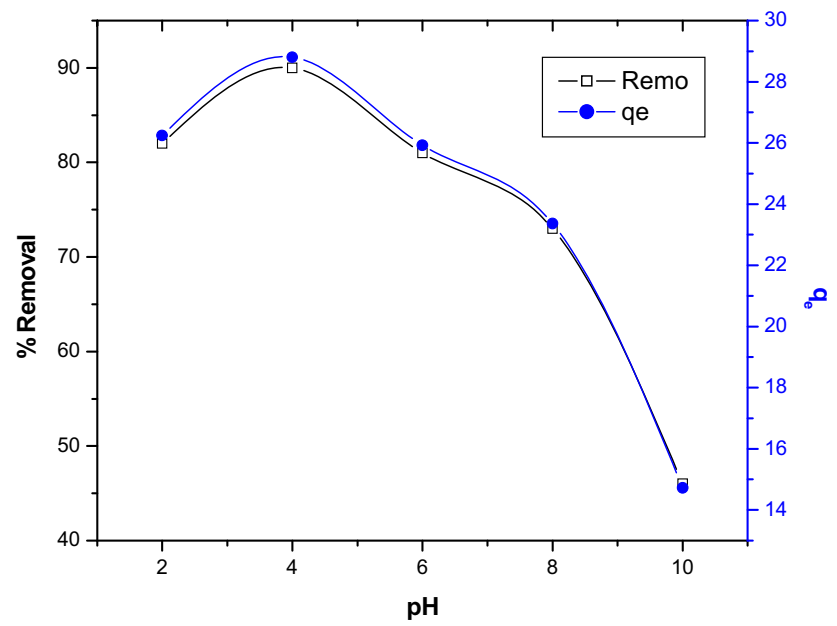

Fig. 3 Effect of $\mathrm{pH}$ 
solution. This phenomenon nicely interpreted with the help of ZPC of NBP. From the Fig. 1, it is clear that the ZPC of NBP is 5.63 and maximum $\mathrm{F}$ adsorption occurs at $\mathrm{pH} 4$ which is below the $\mathrm{pH}$ zpc of NBP. That means the main driving force of $\mathrm{F}$ adsorption is purely electrostatic in nature [20] as per the Eqs. (4) and (3):

$$
\begin{aligned}
& \mathrm{NBP} \ldots . . \mathrm{OH}+\mathrm{H}_{3} \mathrm{O}^{+}+\mathrm{F}^{-} \quad \mathrm{NBP} \ldots . . \mathrm{OH}_{2}{ }^{+} \ldots \ldots \mathrm{F}^{-} \\
& \mathrm{NBP} \ldots . . \mathrm{OH}+\mathrm{Na}^{+}+\mathrm{OH}^{-} \\
& \quad+\mathrm{F}^{-} \quad \mathrm{NBP}-\mathrm{O}^{-} \ldots \ldots . \mathrm{Na}^{+} \ldots \ldots . \mathrm{F}^{-}+\mathrm{H}_{2} \mathrm{O}
\end{aligned}
$$

The removal of fluoride at lower $\mathrm{pH}$ is also reported by the earlier researchers $[14,18,20]$. Almost similar observation was reported by yadav et al. [27] in their earlier work where they argued that under acidic condition, the surface of the adsorbent changes to positive change which facilitate the fluoride adsorption through anion exchange.

\section{Effect of Initial Concentration}

The effect of initial concentration of fluoride is depicted in the Fig. 4. From the Fig. 4, it is clear that fluoride removal increased with increasing influent concentration from 2.0 to $20.0 \mathrm{mg} / \mathrm{L}$. and maximum fluoride uptake of $0.96 \mathrm{mg} / \mathrm{g}$ was recorded at $30.08 \mathrm{mg} / \mathrm{L}$. This could be attributed to the possible higher interaction between $\mathrm{F}$ ions and the binding sites on the NBP surface and saturation of all binding sites with $\mathrm{F}$ ions. Therefor, it was inferred that higher concentration of $\mathrm{F}$ in the solution is responsible for the increase in the percentage of $\mathrm{F}$ removal until the saturation of the NBP biomass is atained. Almost similar uptake pattern of fluoride was reported by Koilraj and Kannan [1].

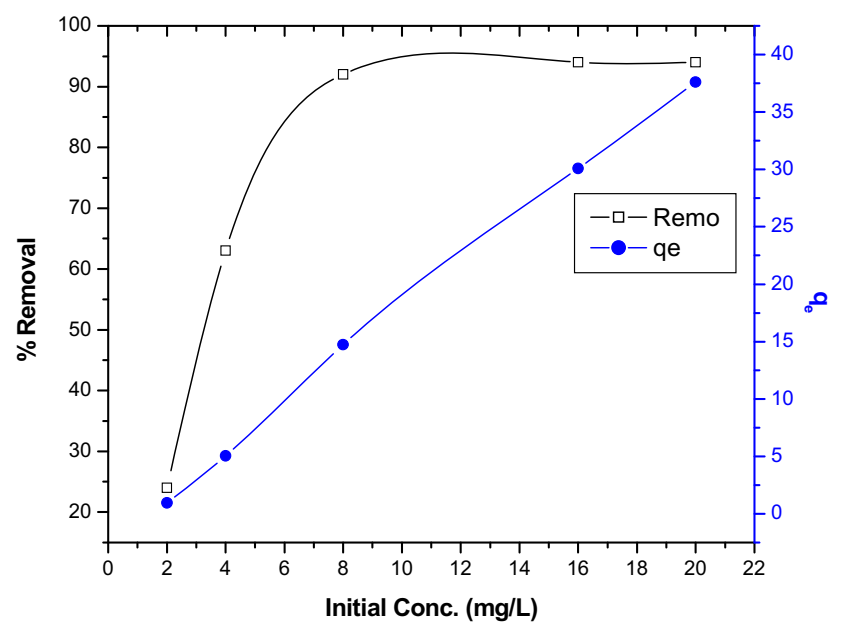

Fig. 4 Effect of initial conc. (mg/L)

\section{Effects of Adsorbent Dose}

The fluoride removal increases with the amount of NBP used (Fig. 5). From the Fig. 5, it is clear that, when the adsorbent amount increased from 0.1 to $0.15 \mathrm{~g} / 100 \mathrm{ml}$, the fluoride removal increased from 89 to $96.7 \%$, respectively. This gradual increment is due to the enhancement of the surface area which promoted the sorption of fluoride [12]. On the other hand, the adsorption capacity $\left(\mathrm{q}_{\mathrm{e}} \mathrm{mg} / \mathrm{g}\right)$ value decreased for a fixed influent (fluoride) concentration $(16 \mathrm{mg} / \mathrm{L})$ with the increase of adsorbent dose. This finding nicely fitted with the increase of adsorbent dose for a fixed solute load, and surface sites heterogeneity of the adsorbent [28]. According to surface site heterogeneity model, the surface is composed of sites with a spectrum of binding energies at the high adsorbent dose, the availability of higher energy sites decreases with a large fraction of lower energy sites occupied, resulting in a low qe value. However, at lower adsorbent dose, all types of sites entirely exposed and the adsorption on the surface is saturated faster showing a higher $\mathrm{q}_{\mathrm{e}}$ value $[29,30]$.

\section{Effect of Contact Time}

Figure 6 shows fluoride removal at different contact times using NBP as biosorbent. With increasing contact time, fluoride removal increased rapidly. However, after reaching maximum value (94\%), removal gradually approached a more or less constant value indicating attainment of equilibrium. The adsorption nature of fluoride on NBP may be considered to be occurring in three distinct phases. In the first phase, rapid adsorption occurs. This may be the results of instantaneous sorption of fluoride on the surface of NBP. In the second phase, sorption of fluoride decrease. This is perhaps due to migration of fluoride from boundary layer to the interior pore [12]. In the third phase, the entire adsorption process attained equilibrium at $60 \mathrm{~min}$ due to non-availability of active sites.

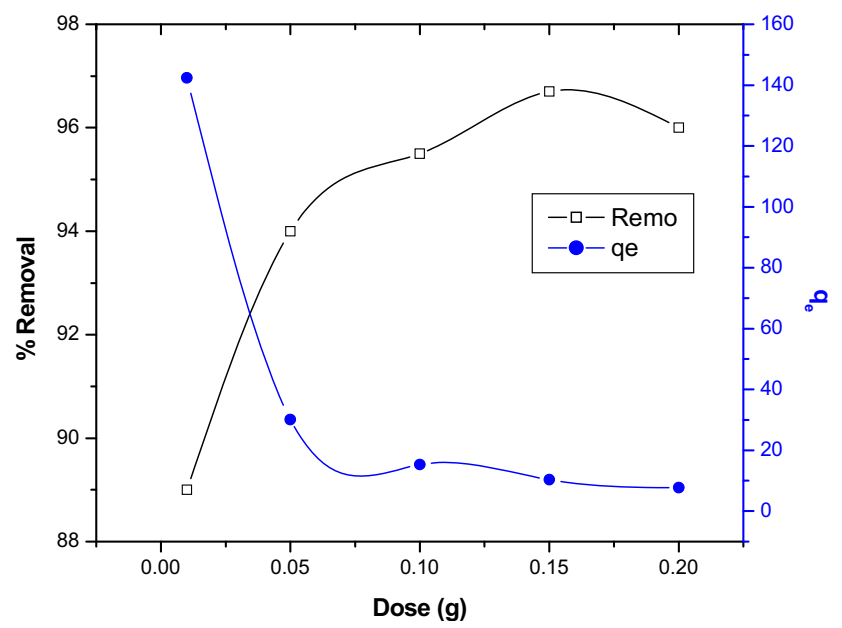

Fig. 5 Effect of adsorbent dose (g) 


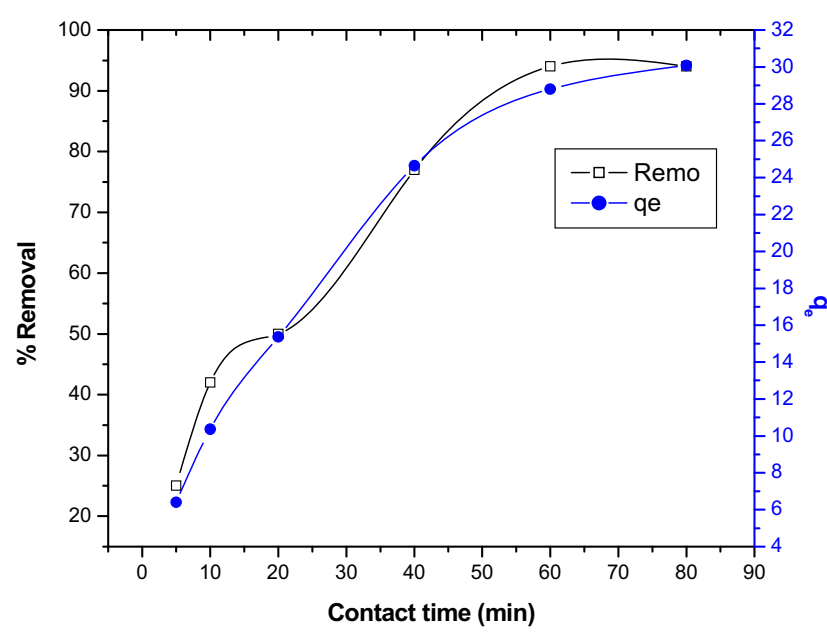

Fig. 6 Effect of contact time (min)

Almost similar observation reported by Nasr et al. [12] and Fan et al. [31]. As after $60 \mathrm{~min}$ there is no further improvement in fluoride adsorption, an equilibrium time of $60 \mathrm{~min}$ was chosen for all subsequent experiments.

\section{Effect of Temperature}

Temperature is a crucial parameter in adsorption process. The effect of temperature on fluoride removal was studied in the solution temperature range from 300 to $333 \mathrm{~K}$ and it is presented in Fig. 7. It reveals that fluoride removal decreased with the increase in temperature. This result suggests higher temperature did not favor adsorption of F ions. The removal efficiency of fluoride at higher temperature can be attributed by the fact that the molecules get excitation at higher temperature and ultimately breakdown the attractive force between surface atom of the adsorbent and fluoride [32].

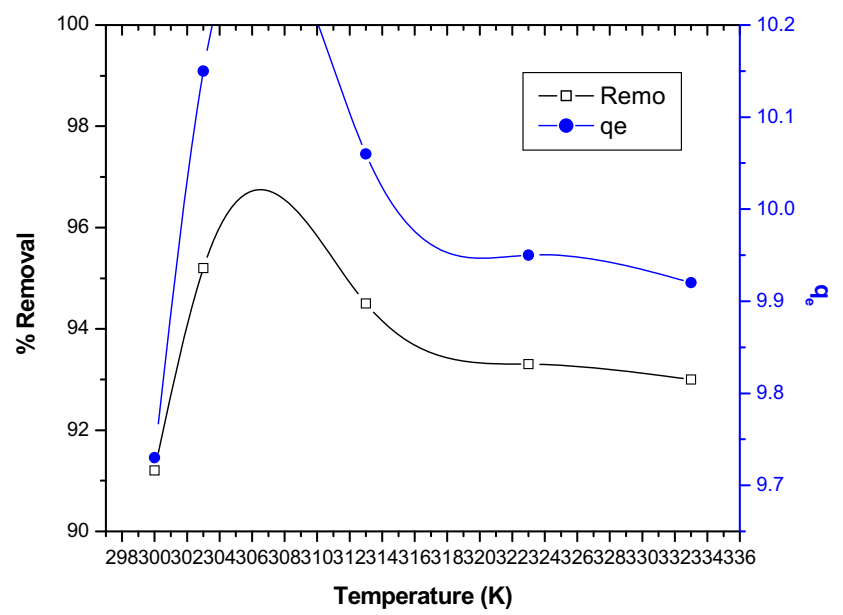

Fig. 7 Effect of temperature (g)

\section{Effect of Co-ions on Fluoride Uptake}

In general, field samples contain many anions besides the anion of interest. Therefore, the study of fluoride uptake in presence of other co-ions is highly desirable with respect to environmental contamination point of view. Present study was conducted with the anions such as carbonate, nitrate, sulfate, chloride, and phosphate and the results are presented in Fig. 8. The concentration of fluoride was taken as $30 \mathrm{mg} / \mathrm{L}$ along with $50 \mathrm{mg} / \mathrm{L}$ concentration other co-ions. Results revealed that fluoride uptake strongly influenced by carbonate followed by phosphate and sulfate. The strong interference of fluoride uptake by carbonate is due to the preferential binding of carbonate on the surface of adsorbent [33]. The interference of phosphate is also reported by earlier researcher [34]. The relative interference of fluoride uptake by co-ions is in the order of $\mathrm{CO}_{3}{ }^{2-}>\mathrm{PO}_{4}{ }^{3-}>\mathrm{SO}_{4}{ }^{2-}>\mathrm{NO}_{3}{ }^{-}>\mathrm{Cl}^{-}$.

\section{Isotherm Study on Fluoride Adsorption}

The entire biosorption of fluoride on NBP was assessed by using widely used four isotherms namely Langmuir, Freundlich, and D-R, and Temkin. Results revealed that among the four isotherms, Freundlich isotherm [35] nicely fitted with high correlation coefficient, suggesting multilayer adsorption of fluoride on NBP. The dimensionless separation factors $\left(\mathrm{R}_{\mathrm{L}}\right)$ suggested that the fluoride adsorption is favorable as the values of $R_{L}$ less than 1 and greater than zero for all studied initial concentration of fluoride [36]. All the isotherms constant along with the regression coefficients $\left(R_{L}\right)$ are provided in the Table 2. From Table 2, it is clear that the maximum adsorption capacity was recorded as $16.14 \mathrm{mg} / \mathrm{g}$ from D$\mathrm{R}$ equation and the value is higher than Langmuir isotherm [37]. $\mathrm{K}_{\mathrm{L}}(\mathrm{L} / \mathrm{g})$ is the adsorption constant related to the affinity

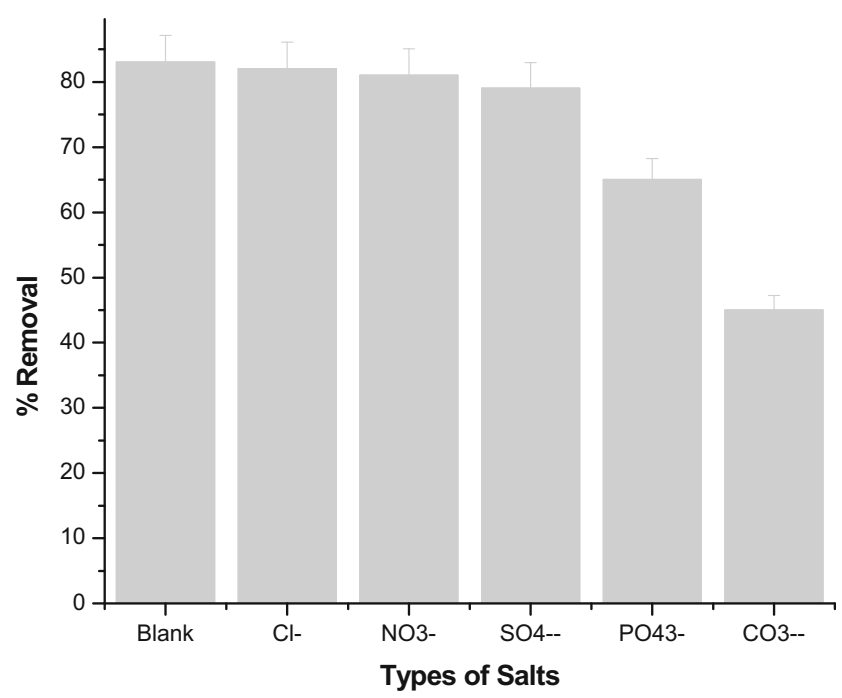

Fig. 8 Effect of interfering ions for fluoride removal on NBP 
Table 2 Parameters of isotherm models on adsorption of fluoride by NBP

\begin{tabular}{lll}
\hline $\begin{array}{l}\text { Isotherm } \\
\text { model }\end{array}$ & Equation & Parameters \\
\hline Langmuir & $\frac{1}{\mathrm{q}_{\mathrm{e}}}=\frac{1}{\mathrm{~K}_{\mathrm{L}} \mathrm{q}_{\mathrm{m}}} \frac{1}{\mathrm{C}_{\mathrm{e}}}+\frac{1}{\mathrm{qm}}$ & $\mathrm{K}_{\mathrm{L}}=0.13$ \\
& & $\mathrm{R}_{\mathrm{L}}=0.842$ \\
& & $\mathrm{q}_{\mathrm{m}}=1.212$ \\
& $\mathrm{R}^{2}=0.246$ \\
Freundlich & $\operatorname{logq}_{\mathrm{e}}=\log \mathrm{K}_{\mathrm{f}}+\frac{1}{\mathrm{n}} \log \mathrm{C}_{\mathrm{e}}$ & $\mathrm{K}_{\mathrm{f}}=1.321$ \\
& & $n=8.26$ \\
& & $\mathrm{R}^{2}=0.314$ \\
D-R & $\operatorname{lnq}_{\mathrm{e}}=\ln \mathrm{q}_{\mathrm{DR}}-\mathrm{K}_{\mathrm{DR}} \mathrm{R}^{2} \mathrm{~T}^{2} \ln \left(1+\frac{1}{\mathrm{C}_{\mathrm{e}}}\right)$ & $\mathrm{q}_{\mathrm{max}}=16.4$ \\
& & $\mathrm{E}_{\mathrm{S}}=6.12 \times 10^{-6}$ \\
& & $\mathrm{R}^{2}=0.995$ \\
Temkin & $\mathrm{q}_{\mathrm{e}}=\mathrm{B}_{\mathrm{T}} \ln \mathrm{K}_{\mathrm{T}}+\mathrm{B}_{\mathrm{T}} \ln \mathrm{C}_{\mathrm{e}}$ & $\mathrm{B}_{\mathrm{T}}=0.007$ \\
& & $\mathrm{~K}_{\mathrm{T}}=3.036 \times 10^{-15}$ \\
& & $\mathrm{R}^{2}=0.110$ \\
& &
\end{tabular}

of binding sites $(\mathrm{L} / \mathrm{g})$ and lower values of $\mathrm{K}_{\mathrm{L}}(0.13)$ indicate that the particles radius of adsorbent was small towards adsorption [38]. Moreover, the adsorption energy (E) was also calculated from D-R equation and it clearly revealed that fluoride adsorption onto the NBP is absolutely physisorption in nature (as the value of $\mathrm{E}<8$ ). Table 2 also provides the valuable information regarding heat of adsorption $\left(\mathrm{B}_{\mathrm{T}}\right)$ and Temking isotherm binding constant, $\mathrm{K}_{\mathrm{T}}(\mathrm{L} / \mathrm{min})$. Results indicate that the value of $\mathrm{B}_{\mathrm{T}}<8$, therefore, interaction between $\mathrm{F}$ and NBP is purely physisorption in nature.

\section{Kinetic Study in Adsorption of Fluoride}

The kinetics of fluoride adsorption by NBP was assessed by the use of pseudo-first-order, pseudo-second-order, intraparticles diffusion and Bahangam kinetic models. The adsorption kinetics not only describes the adsorption mechanism of adsorbates on the adsorbents but also describes the adsorption rate which controls the contact time of adsorbates at the solid-liquid interface [39]. The linearized forms of all the four kinetics models along with different constant terms and regression coefficient values are presented in Table 3. From the Table 3, it is clear that biosorption kinetics nicely fitted with Bahangam equation and pseudo-second-order kinetics. However, pseudo-first-order and intraparticles models showed moderate agreement with the studied results. The kinetics of adsorbate-adsorbent interaction depends on many factors such as nature of adsorbate and adsorbent, $\mathrm{pH}$ of the aqueous medium, temperature of the adsorption reaction, average time of contact between adsorbate and adsorbent and mass transport process [40]. The data were further used to investigate the slow step occurring in the present adsorption system. The applicability of Bahangam's equation was given by Aharoni and Ungarish [41]. As such $\log \log \left[\mathrm{C}_{0} /\left(\mathrm{C}_{0}-\mathrm{q}_{\mathrm{t}} \mathrm{m}\right)\right]$ was plotted against $\log \mathrm{t}$ (Figure not shown) and the constant values presented in Table 3. The plot was found liner indicating that kinetics confirmed to Bahangam's equation and therefore the adsorption of fluoride on NBP was pore diffusion control [42].

\section{Thermodynamic Parameters}

The entire biosorption of fluoride by NBP were calculated by the following Eqs. (5-6):

$\Delta G^{0}=-R T \ln k$

$\Delta G^{0}=\frac{\Delta S^{0}}{R}-\frac{\Delta H^{0}}{R T}$

where $\Delta G^{0}, \Delta S^{0}$, and $\Delta H^{0}$ are the thermodynamics parameters free energy, entropy and enthalpy, respectively, and

Table 3 Parameters of kinetic models on adsorption of fluoride by NBP

\begin{tabular}{|c|c|c|}
\hline Kinetic model & Equation & NBP \\
\hline Pseudo-first-order & $\log \left(q_{e}-q_{t}\right)=\log q_{e}-\frac{k_{1} t}{2.303}$ & $\begin{array}{l}\mathrm{q}_{\mathrm{e} 1}=1.94 \\
\mathrm{~K}_{1}=1.08 \times 10^{2} \\
\mathrm{R}^{2}=0.982\end{array}$ \\
\hline Pseudo-second-order & $\frac{t}{q_{t}}=\frac{1}{k_{2} q_{e}{ }^{2}}+\frac{t}{q_{e}}$ & $\begin{array}{l}\mathrm{q}_{\mathrm{e} 2}=37.6 \\
\mathrm{~K}_{2}=5.78 \times 10^{-4} \\
\mathrm{R}^{2}=0.991\end{array}$ \\
\hline $\begin{array}{c}\text { Intra-particle } \\
\text { diffusion }\end{array}$ & $q_{e}=k_{i d} t^{0.5}+C$ & $\begin{array}{l}\mathrm{K}_{\mathrm{it}}=0.262 \\
I=0.643 \\
\mathrm{R}^{2}=0.977\end{array}$ \\
\hline Bahangam equation & $\log \log \left[\frac{C_{0}}{\left(C_{0}-q_{t} m\right)}\right]=\log \left(\frac{K_{0} m}{2.303}\right)+\alpha \log t$ & $\begin{array}{l}\alpha=0.974 \\
\mathrm{~K}_{0}=7.664 \\
\mathrm{R}_{2}=1.00\end{array}$ \\
\hline
\end{tabular}


Table 4 Thermodynamic parameters on adsorption of fluoride by NBP

\begin{tabular}{lll}
\hline $\begin{array}{l}\text { Thermodynamic } \\
\text { parameters }\end{array}$ & $\begin{array}{l}\text { Temperature } \\
(\mathrm{K})\end{array}$ & NBP \\
\hline$\Delta \mathrm{G}^{0}$ & 300 & -5831.44 \\
& 303 & -7524.68 \\
& 313 & -7400.89 \\
& 323 & -7073.40 \\
& 333 & -7162.27 \\
$\Delta \mathrm{H}^{0}$ & & $-8.86 \times 10^{2}$ \\
$\Delta \mathrm{S}^{0}$ & & $0.84 \times 10^{2}$ \\
\hline
\end{tabular}

other two constants are $K$ (is the distribution co-efficient $\left(K=\frac{q_{e}}{C_{e}}\right)$ ) and $R$ ( is the universal gas constant). The Van't Hoff plot of $\ln _{\mathrm{c}}$ against $1 / \mathrm{T}$ (plot not shown) was used to calculate the free energy $\left(\Delta G^{0}\right)$, entropy $\left(\Delta S^{0}\right)$, and enthalpy $\left(\Delta H^{0}\right)$ by varying temperature from 313 to $343 \mathrm{~K}$, and the calculated value is depicted in Table 4. The results suggest that the $\mathrm{F}$ adsorption is not favorable at higher temperature. Moreover, the negative value of enthalpy change indicated that fluoride biosorption on NBP was exothermic [43]. The positive entropy change during adsorption was due to gain of translational degree of freedom [44]. The negative free
Table 5 Comparison of the defluoridation capacities of different biomass

\begin{tabular}{|c|c|c|}
\hline Name of adsorbent & $\begin{array}{l}\text { Adsorption capacity } \\
(\mathrm{mg} / \mathrm{g})\end{array}$ & Reference \\
\hline Used tea leaves & 0.51 & [46] \\
\hline Cynodon dactylon-based activated carbon & 4.617 & {$[47]$} \\
\hline Fungal biomass (Pleurotus ostreatus 1804) & 1.272 & [48] \\
\hline Treated banana peel & 0.395 & [49] \\
\hline Treated coffee husk & 0.416 & [49] \\
\hline Activated rice husk & 0.426 & [19] \\
\hline Tea ash & 8.55 & {$[14]$} \\
\hline Eggshell dust & 1.09 & {$[17]$} \\
\hline \multicolumn{3}{|l|}{ Lemon leaf dust } \\
\hline $\begin{array}{l}\text { LLD-1 } \\
\text { LLD-2 }\end{array}$ & $\begin{array}{l}7.63 \\
27.03\end{array}$ & \multirow[t]{2}{*}{ [16] } \\
\hline LLD-3 & 38.46 & \\
\hline \multicolumn{3}{|l|}{ Coconut fiber dust (CFD) } \\
\hline $\begin{array}{l}\text { CFD-1 } \\
\text { CFD-2 }\end{array}$ & $\begin{array}{l}12.66 \\
25.64\end{array}$ & \multirow[t]{2}{*}{ [15] } \\
\hline CFD-3 & 38.46 & \\
\hline Aspergillus & 8.09 & {$[50]$} \\
\hline Ca-pretreated Aspergillus tea ash & 4.8 & {$[50]$} \\
\hline Rice husk ash (RHA) by coating $\mathrm{Al}(\mathrm{OH})_{3}$ & $9-10$ & {$[51]$} \\
\hline $\begin{array}{l}\text { Zirconium impregnated cashew nut (Anacardium occidental) shell } \\
\text { carbon }\end{array}$ & 1.83 & {$[52]$} \\
\hline Eichhornia crassipes biomass carbon at $300^{\circ} \mathrm{C}$ & 0.52 & {$[53]$} \\
\hline Aluminum impregnated coconut fiber ash & 3.192 & {$[33]$} \\
\hline Aluminum impregnated & 34.48 & {$[24]$} \\
\hline $\begin{array}{l}\text { Potato plant ash } \\
\text { Lichen }\end{array}$ & 0.81 & [54] \\
\hline Ca-pretreated lichen & 1.72 & {$[54]$} \\
\hline Activated silica gel & 0.308 & {$[19]$} \\
\hline Calcium carbonate & 12.5 & {$[55]$} \\
\hline Activated alumina & 1.2 & {$[55]$} \\
\hline Activated sugarcane ash & 10.99 & {$[55]$} \\
\hline Saw dust raw & 1.73 & {$[20]$} \\
\hline Wheat straw raw & 1.93 & {$[20]$} \\
\hline Activated bagasse carbon & 1.15 & {$[20]$} \\
\hline Natural banana (Musa acuminate) peel & 1.212 & $\begin{array}{l}\text { Present } \\
\text { study }\end{array}$ \\
\hline
\end{tabular}


Table 6 Variation of water quality parameters of field samples

\begin{tabular}{lccc}
\hline Parameters & Alampur & Saldha & Nasipur \\
\hline $\mathrm{pH}$ & 7.56 & 7.81 & 7.63 \\
$\mathrm{EC}(\mu \mathrm{S} / \mathrm{cm})$ & 2041 & 3011 & 2716 \\
$\mathrm{Cl}(\mathrm{mg} / \mathrm{L})$ & 41.75 & 35.71 & 157.7 \\
$\mathrm{SO}_{4}{ }^{2-}(\mathrm{mg} / \mathrm{L})$ & 130.4 & 95.3 & 120.1 \\
$\mathrm{PO}_{4}{ }^{3-}(\mathrm{mg} / \mathrm{L})$ & 13.5 & 7.1 & 0.51 \\
$\mathrm{Fe}^{3+}$ & 0.211 & 0.52 & 0.64 \\
$\mathrm{TDS}(\mathrm{mg} / \mathrm{L})$ & 633.1 & 548.8 & 600.9 \\
$\mathrm{TH}(\mathrm{mg} / \mathrm{L})$ & 175.5 & 160.0 & 184.6 \\
$\mathrm{~F}(\mathrm{mg} / \mathrm{L})$ & 3.12 & 14.22 & 2.51 \\
\hline
\end{tabular}

energy change with increasing temperature suggests the feasibility of the process and its spontaneous nature [45].

\section{Comparison with Other Adsorbents}

In order to compare the adsorption capacity of the studied adsorbent with previously reported adsorbents, a comprehensive table has been provided (Table 5). From the Table 5, it is clear that the adsorbents such as Cynodon dactylon-based activated carbon, lemon leaf dust (LLD-1, LLD-2 and LLD-3), and coconut fiber dust (CFD-1, CFD2 and CFD-3) showed moderate to high fluoride adsorption capacity ranging from 4.617 to $38.46 \mathrm{mg} / \mathrm{g}$. However, the other adsorbents such as used tea leaves, treated banana peel, treated coffee husk, activated rice husk, Eichhornia crassipes, lichen, and activated silica gel showed low fluoride adsorption capacity (ranges from 0.395 to 0.81 ). The present adsorbent showed the adsorption capacity $1.212 \mathrm{mg} / \mathrm{g}$ and it is better than activated bagasse carbon, activated alumina, eggshell dust, and fungal biomass (Table 5).

\section{Biosorption of Fluoride from Filed Samples}

In order to check the efficacy of tested adsorbent, batch studies were conducted to evaluate the adsorption performance of the filed samples. The samples were collected from three fluoride affected villages of Birbhum district, West Bengal, India. Initially physic-chemical parameters along with fluoride level were measured and depicted in Table 6 . The entire batch adsorption was performed with the best optimized conditions of the banana peel (dose $0.15 \mathrm{~g} / 100 \mathrm{ml} ; \mathrm{pH} 4.0$; contact time $60 \mathrm{~min}$; temperature $302 \mathrm{~K}$ ). The studied adsorbent removed fluoride as $83.65,78.83$, and $98.80 \%$ for the water samples collected from the villages of Alampur, Saldha, and Nasipur, respectively.

\section{Conclusions}

Research was carried out to explore banana peels as a high capacity, economically viable, and low-cost adsorbent for removal of fluoride. Adsorbent characterization has been done by $\mathrm{pH}_{\mathrm{ZPC}}$, SEM, and FT-IR studies. The $\mathrm{pH}$ played pivotal on the sorbate adsorption capacity onto the natural banana peel biosorbent. The decrease in the solution $\mathrm{pH}$ led to a significant increase in the adsorption capacities of all parameters on the banana peel biosorbent with maximum adsorption capacity. Batch study results indicate that best fluoride removal condition is $10 \mathrm{mg} / \mathrm{L}$ initial fluoride concentration, $0.15 \mathrm{~g} 100 \mathrm{ml}$ adsorbent dose, $\mathrm{pH}$ 6.0, and contact time $60.0 \mathrm{~min}$. Isotherm of the batch study best fitted with D-R isotherm model with high $R^{2}(0.995)$ values. The kinetics of the batch study clearly demonstrated that fluoride adsorption on banana peel dust is nicely fitted with Bahangam and pseudo second-order kinetic models, and thermodynamic study suggests that the defluridation with NBP is an exothermic process. The relative interference of fluoride uptake by co-ions is in the order of $\mathrm{CO}_{3}{ }^{2-}>\mathrm{PO}_{4}{ }^{3-}>\mathrm{SO}_{4}{ }^{2-}>\mathrm{NO}_{3}{ }^{-}>\mathrm{Cl}^{-}$. Finally, the studied adsorbent showed excellent performance towards removal of fluoride from field samples. Therefore, the use of banana peel could be a cost-effective adsorbent and may provide an alternative method for removal of fluoride from contaminated water.

Acknowledgements The authors are grateful to Dr. Rajarshi Ghosh, Assistant Professor, Department of Chemistry, Burdwan University, Burdwan, West Bengal, India for recording FTIR data and they also extend their gratitude to Dr. Srikanta Chakraborty, Incharge of SEM, USIC, University of Burdwan, West Bengal, India for SEM study.

\section{References}

1. Koilraj P, Kannan S (2013) Aqueous fluoride removal using $\mathrm{ZnCr}$ layered double hyroxides and their polymeric composites: batch and column studies. Chem Eng J 234:406-415

2. Bhaumik R, Mondal NK (2014) Adsorption of fluoride from aqueous solution by a new low-cost adsorbent: thermally and chemically activated coconut fibre dust. Clean Techn Environ Policy DOI. doi:10.1007/s10098-015-0937-6

3. Mondal NK, Das B, Bhaumik R, Bour T, Roy P (2012) Calcareous soil as a promising adsorbent to remove fluoride from aqueous solution: equilibrium, kinetic and thermodynamic study. J Modern Chem Technol 3(3):1-21

4. Trivedi MH, Verma RJ, Chinoy NJ et al (2007) Effect of high fluoride water on intelligence of school children in India. Fluoride 40:178-183

5. Peckham S, Lowery D, Spencer S (2015) Are fluoride levels in drinking water associated with hypothyroidism prevalence in England? A large observational study of GP practice data and fluoride levels in drinking water. J Epidemiol Commu Health 0:1-6. doi:10.1136/jech-2014-204971

6. Das C, Dey U, Chakraborty D, Datta JK, Mondal NK (2015) Fluoride toxicity effects in potato plant (Solanum tuberosum 1.) grown in contaminated soils. Octa J EnvironRes 3(2):136-143 
7. Maitra A, Datta JK, Mondal NK (2013) Amelioration of fluoride toxicity with the use of indigenous inputs. J Stress Physiol Biochem 9(3):207-219

8. WHO (2011) Guideline for drinking-water quality, 4th edn. WorldHealth Organization, Geneva

9. Meenakshi, Maheshwari RC (2006) Fluoride in drinking water and its removal. J Hazard Matter 137(1):456-463

10. Kameda T, Oba J, Yoshioka T (2015) Recyclable Mg-Al layered double hydroxides for fluoride removal: kinetic and equilibrium studies. J Hazard Mater 300:475-482

11. Kabay N, Arar O, Samatya S, Yüksel U, Yüksel M (2008) Separation of fluoride from aqueous solution by electrodialysis: effect of process parameters and other ionic species. J Hazard Mater 153:107-113

12. Nasar AB, Walha K, Charcosset C, Amar RB (2011) Removal of fluoride ions using cuttle fish bones. J Fluoride Chem 132:57-62

13. Mondal NK, Bhaumik R, Roy P, Das B, Datta JK (2013) Investigation on fixed bed column performance of fluoride adsorption by sugarcane charcoal. J Environ Biol 34:1059-1064

14. Mondal NK, Bhaumik R, Bour T, Das B, Roy P, Datta JK (2012) Studies on defluoridation of water by tea ash: an unconventional biosorbent. Chem Sci Tranction 1(2):239-256

15. Bhaumik R, Mondal NK (2015) Adsorption of fluoride from aqueous solution by a new low-cost adsorbent: thermally and chemically activated coconut fiber dust. Clean Techn Environ Policy. doi:10.1007/s10098-015-0937-6

16. Bhaumik R, Mondal NK, Chattoraj S, Datta JK (2013) Application of response surface methodology for optimization of fluoride removal mechanism by newly developed biomaterial. Am J Anal Chem 4:404-419

17. Bhaumik R, Mondal NK, Das B, Roy P, Pal KC, Das C, Banerjee A, Datta JK (2012) Eggshell powder as an adsorbent for removal of fluoride from aqueous solution: equilibrium, kinetic and thermodynamic studies. E J Chemistry 29(3):1457-1480

18. Mondal NK, Das B, Bhaumik R, Roy P (2012c) Calcareous soil as a promising adsorbent to remove fluoride from aqueous solution: equilibrium, kinetic and thermodynamic study. J Mod Chem Chemi Technol 3(3):1-12

19. Mondal NK, Bhaumik R, Banerjee A, Datta JK, Baur T (2012) A comparative study on the batch performance of fluoride adsorption by activated silica gel and activated rice husk ash. Inter J Environ Sci 2(3):1643-1661

20. Tripathy SS, Bersillon JL, Gopal K (2006) Removal of fluoride from drinking water by adsorption onto alum-impregnated activated alumina. Sep Purif Technol 50:310-317

21. Kumar E, Bhatnagar A, Ji M, Jung W, Lee SH, Kim SJ, Lee G, Song H, Choi JY, Yang JS, Jeon BH (2009) Defluoridation from aqueous solutions by granular ferric hydroxide (GFH). Water Res 43:490-498

22. Abbasi Z, Alikarami M, Nezhad ER, Moradi F, Moradi V (2013) Adsorptive removal of $\mathrm{Co}^{2+}$ and $\mathrm{Ni}^{2+}$ by peels of banana from aqueous solution. Univer J Chem 1(3):90-95

23. Memon JR, Memon SQ, Bhanger MI, Memon GZ, El-Turki A, Allen GC (2008) Characterization of banana peel by scanning electron microscopy and FT-IR spectroscopy and its use for cadmium removal. Colloids Surf B: Biointerfaces 66:260-265

24. Mondal MK (2010) Removal of Pb(II) from aqueous solution by adsorption using activated tea waste. Korean J Chem Eng 27(1):144-151

25. Kennedy JH (1990) Analytical chemistry principles, 2nd edn. W.B. Saunders, New York

26. Ghosh SB, Bhaumik R, Mondal NK (2016) Optimization study of adsorption parameters for removal of fluoride using aluminiumimpregnated potato plant ash by response surface methodology. Clean Techn Environ Policy 18:1069-1083

27. Yadav AK, Abbassi R, Gupta A, Dadashzadeh M (2013) Removal of fluoride from aqueous solution and groundwater by wheat straw, sawdust and activated bagasse carbon of sugarcane. Ecol Eng 52: 211-218

28. Chen N, Feng C, Li M (2014) Fluoride removal on Fe-Alimpregnated granular ceramic adsorbent from aqueous solution. Clean Techn Environ Policy 16:609-617

29. Daifullah AAM, Yakout SM, Elreefy SA (2007) Adsorption of fluoride in aqueous solutions using $\mathrm{KMnO} 4$-modified activated carbon derived from stem pyrolysis of rice straw. J Hazard Mater 147:633-643

30. Das N, Pattanaik P, Das R (2005) Defluoridation of drinking water using activated titanium rich bauxite. J Colloid Interface Sci 292:1-10

31. Fan X, Parker DJ, Smith MD (2003) Adsorption kinetics of fluoride on low cost materials. Water Res 37:4929-4937

32. Sujana MG, Anand S (2010) Fluoride removal studies from contaminated ground water by using bauxite. Desalination 267(2-3): 222-227

33. Miyata S (1983) Anion-exchange properties of hydrotalcite-like compounds, clay. Clay Miner 31:305-311

34. Mondal NK, Bhaumik R, Datta JK (2015) Removal of fluoride by aluminium impregnated coconut fiber from synthetic fluoride solution and natural water. Alexandria Eng J. doi:10.1016/j. aej.2015.08.006

35. Freundlich H (1906) Over the adsorption in solution. J Phy Chem 57(A):385

36. Chen N, Zhang Z, Feng C, Li M, Zhu D, Chen R, Sugiura N (2010) An excellent fluoride sorption behaviour of ceramic adsorbent. J Hazard Mater 183:460-465

37. Langmuir I (1918) The adsorption of gases on plane surface of glass, mica, and platinum. J Amer Chem Society 40:1361-1403

38. Anwar J, Shafique U, Zaman W, Salman M, Dar A, Anwar S (2010) Removal of $\mathrm{Pb}(\mathrm{II})$ and $\mathrm{Cd}(\mathrm{II})$ from water by adsorption on peels of banana. Biores Technol 101:1752-1755

39. Ho YS, Porter JF, McKay G (2002) Equilibrium isotherm studies for the sorption of divalent metal ions onto peat: copper, nickel and lead single component systems. Water Air Soil Pollut 141:1-33

40. Achak M, Hafidi A, Ouazzani N, Sayadic S, Mandi L (2009) Low cost biosorbent banana peel for the removal of phenolic compounds from olive mill wastewater: kinetic and equilibrium studies. J Hazard Mater 166:117-125

41. Aharoni C, Ungarish M (1977) Kinetics of activated chemisorptions. Part 2. Theoretical models. J Chem Soc Faraday Trans 73: 456-464

42. Gupta VK, Ali I, Saini VK (2007) Defluoridation of wastewater using waste carbon slurry. Water Res 41:3307-3316

43. Sujana MG, Anand S (2011) Fluoride removal studies from contaminated ground water by using bauxite. Desalination 267:222-227

44. Chen SY, Shen W, Yu F, Wang HP (2009) Kinetic and thermodynamic studies of adsorption of $\mathrm{Cu} 2+$ and $\mathrm{Pb} 2+$ onto amidoximated bacterial cellulose. Polym Bull 63:283

45. Chen L, He S, He B-Y, Wang T-J, C-Li S, Zhang C, Jin Y (2012) Synthesis of iron-doped titanium oxide nanoadsorbent and its adsorption characteristics for fluoride in drinking water. Ind Eng Chem Res 51:13150-13156

46. Methodis PA, Selvapathy P (2005) Studies on removal of fluoride from water by used tea leaves carbon. In: 3rd international conference on plants and Environmental Pollution, Lucknow, India

47. Alagumuthu G, Veeraputhiran V, Venkataraman R (2011) Fluoride adsorption using Cynodon dactylon-based activated carbon. Hem Ind 65:23-35

48. Ramanaiah SV, Venkatamohan S, Rajkumar B, Sarma PN (2006) Monitoring of fluoride concentration in groundwater of Prakasham District in India: correlation with PhysicoChemical parameters. J Environ Sci Engg 48:129-134

49. Getachew T, Hussen A, Rao VM (2015) Defluoridation of water by activated carbon prepared from banana (Musa paradisiaca) peel and coffee (Coffea arabica) husk. Int J Environ Sci Technol 12:1857-1866 
50. Mondal NK, Kundu M, Das K, Bhaumik R, Datta JK (2013a) Biosorption of fluoride from aqueous phase onto aspergillus and its calcium-impregnated biomass and evaluation of adsorption kinetics. Fluoride 46(4):239-245

51. Ganvir V, Das K (2011) Removal of fluoride from drinking water using aluminum hydroxide coated rice husk ash. J Hazard Mater 185:1287-1294. doi:10.1016/j.jhazmat.2010.10.044

52. Alagumuthu G, Rajan M (2010a) Kinetic and equilibrium studies on fluoride removal by zirconium (IV)-impregnated ground nutshell carbon. Hem Ind 64(4):295-304
53. Sinha S, Pandey KP, Mohan D, Singh KP (2003) Removal of fluoride from aqueous solutions by Eichhornia crassipes biomass and its carbonizsed form, Ind. Eng Chem Res 42:6911-6918

54. Mondal NK, Kundu M (2016) Biosorption of fluoride from aqueous solution using lichen and its Ca-pretreated biomass. Water Conserv Sci Eng. doi:10.1007/s41101-016-0009-8

55. Mondal NK, Bhaumik R, Datta JK (2016) Fluoride adsorption by calcium carbonate, activated alumina and activated sugarcane ash. Environ Process. doi:10.1007/s40710-0169-1083 